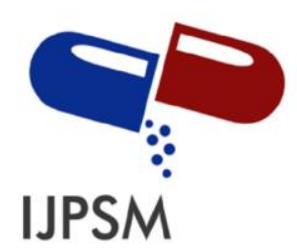

Pooja Patil et al, Int. Journal of Pharmaceutical Sciences and Medicine (IJPSM),

Vol.6 Issue. 2, February- 2021, pg. 24-36

ISSN: 2519-9889

Impact Factor: 3.426

\title{
Development and Validation of a RP-HPLC Method for Simultaneous Quantitation of Resveratrol and Curcumin: Application to Nanolipid Gel Formulation
}

\author{
Pooja Patil $^{1}$; Shilpa Shrotriya ${ }^{2}$; Sugandha Mulgund ${ }^{3}$ \\ ${ }^{1}$ Sinhgad College of Pharmacy \\ ${ }^{2}$ Sinhgad College of Pharmacy \\ ${ }^{3}$ Sinhgad College of Pharmacy, sugandhamulgund@ gmail.com \\ DOI: 10.47760/ijpsm.2021.v06i02.003
}

\begin{abstract}
A new RP-HPLC method for quantitation of resveratrol and curcumin was developed and validated as per ICH Q2 (R1) guideline. Resveratrol and Curcumin shows synergistic effect. Both the drugs either stand alone and in combination have been utilized in the development of many novel formulations. However, no report is available for their identification and quantitation in combined dosage form. This new method was developed for simultaneous quantitation of resveratrol and Curcumin in a Nanolipid gel formulation. The chromatographic conditions were optimized using Hiber C-18 column, $(4.6 \mathrm{~mm} \times 250 \mathrm{~mm}, 5 \mu \mathrm{m})$ with acetonitrile: $0.01 \mathrm{M}$ phosphate buffer $\mathrm{pH}$ adjusted to $4.0 \pm 0.05$ using $1 \% \mathrm{v} / \mathrm{v} o$-phosphoric acid $(60: 40, \mathrm{v} / \mathrm{v})$ as mobile phase. The flow rate was $1 \mathrm{ml} / \mathrm{min}$ and detection was performed at $345 \mathrm{~nm}$. The retention times of resveratrol and curcumin were found to be $3.13 \mathrm{~min}$ and 6.59 min, respectively. Linearity for both the drugs was established in the range of 10-60 $\mu \mathrm{g} / \mathrm{ml}$. The percentage recoveries of resveratrol and curcumin were found to be in the range of 99.5101.75 and 99.01-101.05, respectively. The \% RSD values for intraday and interday precision were found to be 0.10 and 0.8 for resveratrol and 0.30 and 0.58 for curcumin. LOD and LOQ for resveratrol and curcumin were found to be $0.11 \& 0.29 \mu \mathrm{g} / \mathrm{ml}$ and $0.34 \& 0.90 \mu \mathrm{g} / \mathrm{ml}$, respectively. Mean \% assay \pm S.D. for resveratrol and curcumin in Nanolipid gel formulation using the proposed method were found to be $101.67 \pm 0.02$ and 98.66
\end{abstract}

Keywords: Resveratrol, Curcumin, Nanolipid gel, RP-HPLC, Validation

\section{Introduction}

Resveratrol is a phenolic component obtained from skin of grapes, blueberries, raspberries and mulberries. It is an antioxidant and is freely soluble in acetonitrile, methanol and chloroform (Figure 1). It is well known for its anti-inflammatory, analgesic, anti-aging and anticancer activities [Singh G. et.al, 2012]. It enhances the internal functions of the cell, 


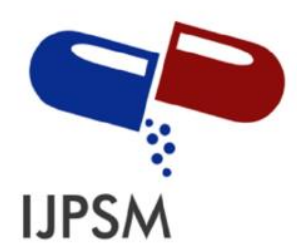

Pooja Patil et al, Int. Journal of Pharmaceutical Sciences and Medicine (IJPSM), Vol.6 Issue. 2, February- 2021, pg. 24-36

ISSN: 2519-9889

Impact Factor: 3.426

particularly mitochondria, which is the energy source for the cell. Mitochondria convert food energy in to energy that the cell can use. Decreased mitochondrial function has been linked to insulin resistance, metabolic syndrome, and cardiovascular disease. Resveratrol has been found to be linked to decreased incidence of many chronic diseases such as neurodegenerative, skin, cancer and heart. [Resveratrol, 2003]

Curcumin is the active component obtained by solvent extraction of turmeric i.e., the ground rhizomes of Curcuma longa L [Priyadarshini KI, 2014] and purification of the extract by crystallization. It is a polyphenolic compound, structurally 1, 7 bis (4-hydroxy-3methoxyphenyl)-1-6-heptadiene-3, 5-dione (Figure 2). [Gavhad G et al, 2005, Curcumin 2004] It is practically insoluble in water but soluble in acetonitrile and chloroform. Curcumin has antioxidant, anti-inflammatory, antiseptic, anti-diabetic, anti-arthritic, antiatherosclerotic properties and is a natural colorant. The principal colouring components of curcumin exhibits keto-enol tautomerism and antioxidative properties. [Gugulothu DB et al 2012]

Many researchers have explored the potential of resveratrol [Chauhan AS, 2017, Caddeoc, 2013, Basavaraj, 2014, Pando D 2015, Ahirrao M et al, 2017, Shrotriya S N et al, 2017] and curcumin [Onoue S, 2010, Mukerjee A 2009, Zhang F 2011] as individual and in combination with each other for development of various formulations as witnessed from many research publications. Literature survey revealed UV-spectrophotometric [Vidhate B et al, 2015], RP-HPLC [Nikolic VD et al 2015, Singh G et al 2012], and mass spectrometric 


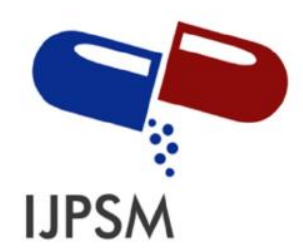

Pooja Patil et al, Int. Journal of Pharmaceutical Sciences and Medicine (IJPSM), Vol.6 Issue. 2, February- 2021, pg. 24-36

ISSN: 2519-9889

Impact Factor: 3.426

[Buiarelli F et al 2006,] methods for estimation of Resveratrol. Similarly, UVSpectrophotometric [Sharma K, 2012, Kadam PV, 2013], LC-MS-MS [Liu A, 2006], HPTLC [Ansari M J, 2005] and RP-HPLC [Dandekar PP, 2009, Li J, 2009] methods have been reported for quantitation of curcumin. As resveratrol and curcumin shows synergistic effect [Gonzales AM, 2008, Majumdar AP 2009] it was considered worthwhile to develop a in-house gel formulation containing both the drugs and to quantitate both the drug by using liquid chromatographic technique. The proposed method is simple, accurate, and reproducible for simultaneous determination of resveratrol and curcumin in combined Nanolipid gel formulation. This paper describes development of a RP-HPLC method which is suitable for routine analysis. The method was validated in compliance with ICH Q2 (R1) guideline [30].

\section{Experimental}

\subsection{Equipment and Materials}

Resveratrol and Curcumin were procured from Yucca enterprises, Mumbai, India. Acetonitrile was purchased from Merck India Pvt Ltd and HPLC grade water was obtained from ELGA Lab water (UHQ- II), Bucks, England. The liquid chromatographic system was Shimadzu (LC-2010 HT, Japan) equipped with a UV-visible detector (SPA-20A), pump LC20AD with a SIL-20 AC HT auto-sampler. The chromatographic analysis was performed using LC solution software on a Hiber C-18 column $(4.6 \times 250 \mathrm{~mm}, 5 \mu \mathrm{m}$ particle size $)$. In addition, an electronic balance (Shimadzu, ATY 224), a pH meter (Equip-tronics, EQ-610) and a sonicator (Spectra Lab, UCB 40) were used in this study. 


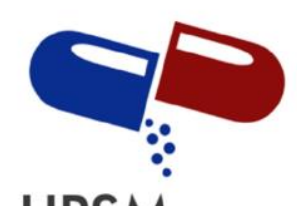

\section{IJPSM}

Pooja Patil et al, Int. Journal of Pharmaceutical Sciences and Medicine (IJPSM),

Vol.6 Issue. 2, February- 2021, pg. 24-36

ISSN: 2519-9889

Impact Factor: 3.426

\subsection{Preparation of Mobile Phase and Stock Solutions:}

Six hundred millilitres of acetonitrile and $400 \mathrm{ml}$ of $0.01 \mathrm{M}$ phosphate buffer $\mathrm{pH}$ adjusted to $4.0 \pm 0.05$ with $1 \% \mathrm{v} / \mathrm{v} o$-phosphoric acid were mixed. Mobile phase was pumped in ratio of $(60: 40, \mathrm{v} / \mathrm{v})$.<smiles>Oc1ccc(/C=C/c2cc(O)cc(O)c2)cc1</smiles>

Figure 1: Structure of Resveratrol<smiles>COc1cc(/C=C/C(=O)/C=C(O)/C=C/c2ccc(O)c(OC)c2)ccc1O</smiles>

Figure 2: Structure of Curcumin

It was sonicated for $10 \mathrm{~min}$ and filtered through $0.22 \mu \mathrm{m}$ nylon membrane filter (Pall, India) before use. Stock solutions were prepared by dissolving $10 \mathrm{mg}$ each of resveratrol and curcumin in $10 \mathrm{ml}$ of diluent to obtain solutions containing $1000 \mu \mathrm{g} / \mathrm{ml}$ of each drug. HPLC analysis was performed on reversed-phase high-performance liquid chromatographic system 


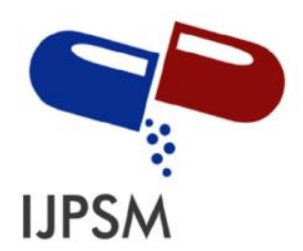

Pooja Patil et al, Int. Journal of Pharmaceutical Sciences and Medicine (IJPSM),

Vol.6 Issue. 2, February- 2021, pg. 24-36

ISSN: 2519-9889

Impact Factor: 3.426

with isocratic elution mode using a mobile phase of acetonitrile: $0.01 \mathrm{M}$ phosphate buffer of pH $4.0 \pm 0.05$ adjusted with $1 \%$ v/v $o$-phosphoric acid (60:40, v/v), on Hiber C-18 column $(4.6 \times 250 \mathrm{~mm}, 5 \mu \mathrm{m}$ particle size). The flow rate was $1 \mathrm{ml} / \mathrm{min}$ and detection $\lambda$ was $345 \mathrm{~nm}$.

\subsection{Calibration curves for Resveratrol and Curcumin}

Appropriate aliquots of resveratrol and curcumin stock solutions were transferred in different $10 \mathrm{ml}$ volumetric flasks and diluted up to the mark with mobile phase to obtain final concentrations of $10-60 \mu \mathrm{g} / \mathrm{ml}$ of each drug. Ten $\mu 1$ from these solutions were injected into column under optimized chromatographic conditions. The chromatograms were recorded and peak areas were noted. Calibration curves were constructed by plotting peak areas versus concentrations and regression equations were computed for both the drugs (Table 1).

TABLE 1: LINEAR REGRESSION DATA FOR CALIBRATION CURVES

\begin{tabular}{|l|c|c|}
\hline \multicolumn{1}{|c|}{ Parameters $($ Units) } & Resveratrol & Curcumin \\
\hline Linearity range $(\mu \mathrm{g} / \mathrm{ml})$ & $10-60$ & $10-60$ \\
$\mathrm{r}^{2} \pm$ S.D. & $0.997 \pm 0.000153$ & $0.9974 \pm 0.000321$ \\
Mean Slope \pm S.D. & $22953.3 \pm 17.89$ & $14770 \pm 50.56$ \\
Mean Intercept \pm S.D. & $2477.5 \pm 783.17$ & $3512.33 \pm 1335.70$ \\
\hline
\end{tabular}

$S . D$ is standard deviation where $n=3$ observations.

\subsection{Formulation of Nanolipid Gel of Resveratrol and Curcumin}

Solid lipid nanoparticles (SLN) of resveratrol ${ }^{[12]}$ and curcumin were prepared by using ultraprobe sonication method and were incorporated in gel base to form Nanolipid gel. Carbopol 940 was used as a gelling agent along with preservatives like methyl and propyl 


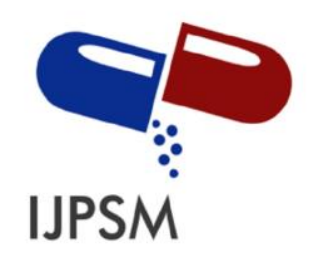

Pooja Patil et al, Int. Journal of Pharmaceutical Sciences and Medicine (IJPSM),

Vol.6 Issue. 2, February- 2021, pg. 24-36

ISSN: 2519-9889

Impact Factor: 3.426

paraben. Triethanolamine was added in the dispersion of Carbopol 940 till it got gel under magnetic stirring.

\subsection{Analysis of Nanolipid gel Formulation}

$10 \mathrm{gm}$ of Nanolipid gel (containing $5 \mathrm{mg}$ each of resveratrol and curcumin) was accurately weighed and transferred into a $100 \mathrm{ml}$ volumetric flask containing $40 \mathrm{ml}$ of acetonitrile and $10 \mathrm{ml}$ of chloroform. It was heated on water bath for 10 mins until gel got dissolved and later diluted upto mark using acetonitrile to obtain final concentration of $50 \mu \mathrm{g} / \mathrm{ml}$ of each drug. The above solution was filtered using $0.45 \mu \mathrm{m}$ nylon filter paper and first few $\mathrm{ml}$ of filtrate was discarded. Appropriate aliquot from stock was transferred to a $10 \mathrm{ml}$ volumetric flask and the volume was made upto the mark with mobile phase to obtain a solution containing $30 \mu \mathrm{g} / \mathrm{ml}$ resveratrol and curcumin. A $10 \mu \mathrm{l}$ volume of above sample solution was injected into HPLC in triplicate under optimized chromatographic conditions and peak areas were measured. Contents of both the drugs were found using regression equations.

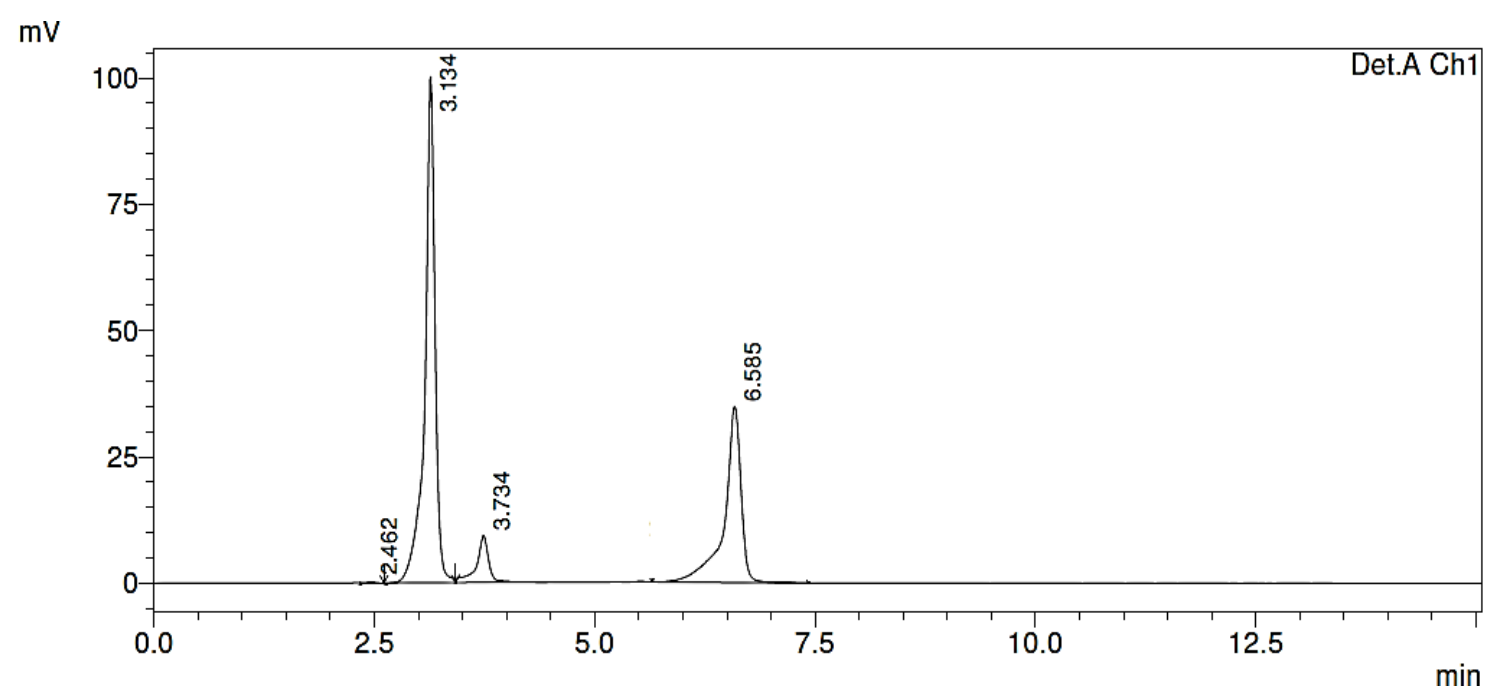

Figure 3: Chromatograph of mixture of Resveratrol and Curcumin, Resveratrol with retention time of $3.13 \mathrm{~min}$ and Curcumin with retention time of $6.59 \mathrm{~min}$. 


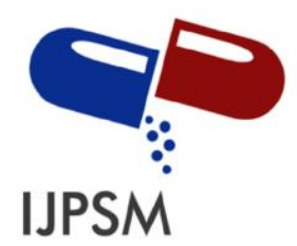

Pooja Patil et al, Int. Journal of Pharmaceutical Sciences and Medicine (IJPSM),

Vol.6 Issue. 2, February- 2021, pg. 24-36

ISSN: 2519-9889

Impact Factor: 3.426

\subsection{Validation}

The method of analysis was validated as per ICHQ2 (R1) guideline ${ }^{[30]}$ for the parameters like precision, accuracy, robustnessand detection limit, quantitation limit. The precision studies (Intraday and Interday) was carried out by estimating the corresponding responses 3 times on the same day and on 3 different days for the concentration of 20,40 and $60 \mu \mathrm{g} / \mathrm{ml}$ respectively. The precision is expressed as the \% RSD of Peak areas and it should not be more than $2 \%$. System suitability tests are an integral part of any chromatographic analysis method which are used to verify reproducibility of the chromatographic system. To ascertain its effectiveness, certain system suitability test parameters were checked by repetitively injecting each drug solution at $50 \mu \mathrm{g} / \mathrm{ml}$ concentration. The results are shown in Table 2 . The accuracy of the method was determined by calculating percentage recovery of resveratrol and curcumin from combined gel formulation. Recovery studies were carried out by applying the method to gel sample containing resveratrol and curcumin at 75, 100 and $125 \%$ levels.

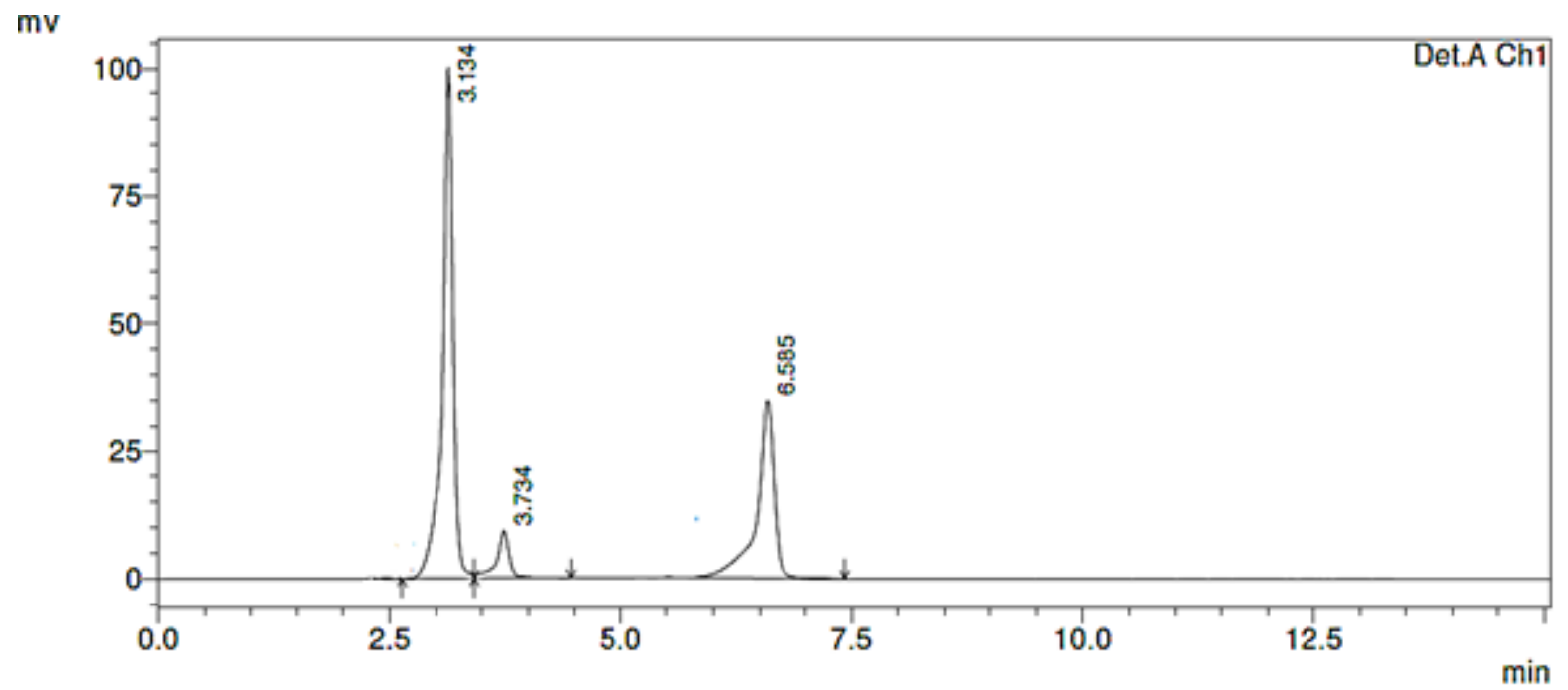

Figure 4: Chromatograph of Nanolipid gel formulation of Resveratrol and Curcumin, Resveratrol with retention time of $3.13 \mathrm{~min}$ and Curcumin with retention time of $6.58 \mathrm{~min}$.

At each level three determinations were carried out and the results obtained were compared.

Robustness of the method was studied by deliberately changing few parameters like percentage of acetonitrile and phosphate buffer in the mobile phase, flow rate and column oven temperature during analysis. One factor was changed at one time to estimate the effect. 


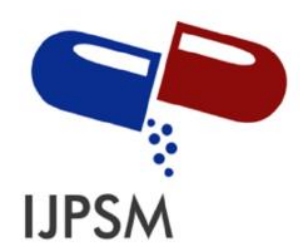

Pooja Patil et al, Int. Journal of Pharmaceutical Sciences and Medicine (IJPSM), Vol.6 Issue. 2, February- 2021, pg. 24-36

ISSN: 2519-9889

Impact Factor: 3.426

Each factor selected was changed at three levels $(-2,0,+2)$ with respect to optimized parameters. Robustness of the method was done at the concentration level of $30 \mu \mathrm{g} / \mathrm{ml}$ for both the drugs and the results are shown in (Table 3). The limit of detection (LOD) and limit of quantitation (LOQ) were calculated using following formulae: $\mathrm{LOD}=3.3(\mathrm{SD}) / \mathrm{S}$ and $\mathrm{LOQ}=10(\mathrm{SD}) / \mathrm{S}$, where $\mathrm{SD}=$ standard deviation of response (peak area) and $\mathrm{S}=$ average of the slope of calibration curve.

\section{Results and Discussion}

Various trials were performed for elution of resveratrol and curcumin by changing mobile phase, column and mobile phase ratio. In the present study, columns from two different manufacturers were tested. Using water: methanol (50:50, v/v) resolution between resveratrol and curcumin was poor. Peak for curcumin was splitted in mobile phase comprising of phosphate buffer and acetonitrile in ratio of 60:40, v/v. In phosphate buffer: acetonitrile (70:30, v/v) peak shape of curcumin was not proper and SST parameters were not within acceptable limits.

The mobile phase consisting of acetonitrile and $0.01 \mathrm{M}$ phosphate buffer having $\mathrm{pH} 4.0 \pm$ 0.05 adjusted with $1 \% \mathrm{v} / \mathrm{v} o$-phosphoric acid in $60: 40 \mathrm{v} / \mathrm{v}$ ratio using $1 \mathrm{ml} / \mathrm{min}$ flow rate gave two sharp, well-resolved peaks with minimum tailing factor for each drug (Figure 3). The retention times for resveratrol and curcumin were $3.13 \mathrm{~min}$ and $6.59 \mathrm{~min}$, respectively. UV overlain spectra of both resveratrol and curcumin showed that both drugs absorbed appreciably at $345 \mathrm{~nm}$, so this wavelength was selected as the detection wavelength. 


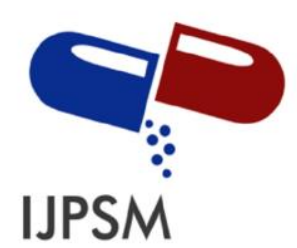

Pooja Patil et al, Int. Journal of Pharmaceutical Sciences and Medicine (IJPSM),

Vol.6 Issue. 2, February- 2021, pg. 24-36

ISSN: 2519-9889

Impact Factor: 3.426

The values of correlation coefficient for both the drugs demonstrated the good relationship between peak area and concentration. Therefore, the developed method was linear in concentration range of $10-60 \mu \mathrm{g} / \mathrm{ml}$ for both the drugs. The data of regression analysis of the calibration curves is shown in Table 1.The results for validation and system suitability test parameters are summarized in Table 2.

TABLE 2: SST PARAMETERS AND SUMMARY OF VALIDATION STUDIES

\begin{tabular}{|c|c|c|}
\hline Parameter (Units) & Resveratrol & Curcumin \\
\hline Retention Time $(\mathrm{min})$ & $3.1 \pm 0.2$ & $6.5 \pm 0.2$ \\
Theoretical Plates & 4821.55 & 10326.03 \\
Tailing Factor (asymmetry factor) & 0.803 & 0.694 \\
Linearity range $(\mu \mathrm{g} / \mathrm{ml})$ & $10-60$ & $10-60$ \\
Correlation coefficient & 0.997 & 0.9974 \\
Precision $(\% \mathrm{RSD})$ & & \\
Interday $(\mathrm{n}=3)$ & 0.8 & 0.58 \\
Intraday $(\mathrm{n}=3)$ & 0.10 & 0.30 \\
Recovery $(\%)$ & $99.5-101.75$ & $99.01-101.05$ \\
Robustness & Robust & Robust \\
LOD $(\mu \mathrm{g} / \mathrm{ml})$ & 0.11 & 0.29 \\
LOQ $(\mu \mathrm{g} / \mathrm{ml})$ & 0.34 & 0.90 \\
Mean Assay $(\%) \pm$ S.D. & $101.67 \pm 0.02$ & $98.66 \pm 0.88$ \\
\hline
\end{tabular}

SST stands for system suitability test

TABLE 3: ROBUSTNESS STUDIESFOR RESVERATROL AND CURCUMIN

\begin{tabular}{|c|c|c|c|}
\hline Factor & Level $^{\mathbf{a}}$ & RESVERATROL $^{b}$ & CURCUMIN $^{b}$ \\
\hline $\begin{array}{l}\text { A. Percentage of acetonitrile and } \\
\text { phosphate buffer in mobile phase }(\mathrm{v} / \mathrm{v})\end{array}$ & & & \\
\hline $58: 42$ & -2 & 3.17 & 6.94 \\
\hline $60: 40$ & 0 & 3.11 & 6.50 \\
\hline $62: 38$ & 2 & 3.00 & 5.75 \\
\hline Mean \pm S.D. & & $3.09 \pm 0.08$ & $6.39 \pm 0.60$ \\
\hline
\end{tabular}




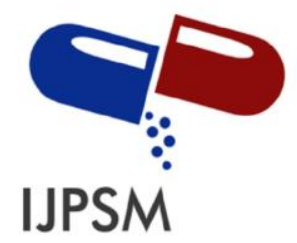

Pooja Patil et al, Int. Journal of Pharmaceutical Sciences and Medicine (IJPSM),

Vol.6 Issue. 2, February- 2021, pg. 24-36

ISSN: 2519-9889

Impact Factor: 3.426

B. Flow rate $(\mathrm{ml} / \mathrm{min})$

0.8

1.0

1.2

Mean \pm S.D.

C. Column Temperature

$28^{\circ} \mathrm{C}$

$30^{\circ} \mathrm{C}$

$32^{\circ} \mathrm{C}$

Mean \pm S.D.

Robustness studies carried out at concentration level of $30 \mu \mathrm{g} / \mathrm{ml},{ }^{a}$ Three factors were slightly changed at three different levels $(-2,2,2)$ and $^{b}$ retention time.

TABLE 4: ACCURACY DATA FOR RESVERATROL AND CURCUMIN

\begin{tabular}{|c|c|c|c|c|c|}
\hline Drug & $\begin{array}{c}\text { Amount added } \\
(\mu \mathrm{g} / \mathrm{ml})\end{array}$ & $\begin{array}{c}\text { Amount Found } \\
(\mu \mathrm{g} / \mathrm{ml}) *\end{array}$ & $\begin{array}{c}\% \\
\text { Recovery* }\end{array}$ & $\begin{array}{c}\text { Mean \% } \\
\text { Recovery } \pm \text { S.D. }\end{array}$ & \% R.S.D. \\
\hline \multirow{3}{*}{ Resveratrol } & 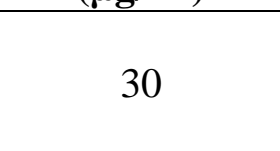 & $\begin{array}{l}30.30 \\
30.22 \\
30.36\end{array}$ & $\begin{array}{l}101.00 \\
101.75 \\
101.22\end{array}$ & $100.32 \pm 0.38$ & 0.37 \\
\hline & 40 & $\begin{array}{l}39.85 \\
40.02 \\
39.95\end{array}$ & $\begin{array}{c}99.62 \\
100.07 \\
99.89\end{array}$ & $99.86 \pm 0.22$ & 0.22 \\
\hline & 50 & $\begin{array}{l}50.13 \\
49.75 \\
50.14\end{array}$ & $\begin{array}{c}100.26 \\
99.5 \\
100.28\end{array}$ & $100.01 \pm 0.44$ & 0.43 \\
\hline \multirow{4}{*}{ Curcumin } & 30 & $\begin{array}{l}30.15 \\
30.27 \\
30.31\end{array}$ & $\begin{array}{l}100.52 \\
100.92 \\
101.05\end{array}$ & $100.83 \pm 0.27$ & 0.26 \\
\hline & 40 & $\begin{array}{l}39.60 \\
39.62\end{array}$ & $\begin{array}{l}99.01 \\
99.07\end{array}$ & \multirow[t]{2}{*}{$99.13 \pm 0.16$} & \multirow[t]{2}{*}{0.16} \\
\hline & & $\begin{array}{l}39.72 \\
50.39\end{array}$ & $\begin{array}{c}99.32 \\
100.78\end{array}$ & & \\
\hline & 50 & $\begin{array}{l}50.19 \\
50.30\end{array}$ & $\begin{array}{l}100.39 \\
100.61\end{array}$ & $100.59 \pm 0.19$ & 0.18 \\
\hline
\end{tabular}

The \%RSD values for intraday and interday precision values were found to be 0.10 and 0.8 for resveratrol and 0.30 and 0.58 for curcumin. The developed method was found to be specific, for quantitation of resveratrol and curcumin as no other peak was observed at the same retention time values of 2 components (Figure 4). 


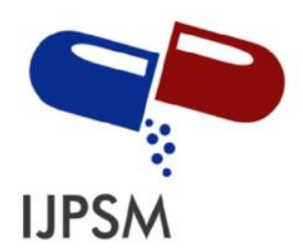

Pooja Patil et al, Int. Journal of Pharmaceutical Sciences and Medicine (IJPSM), Vol.6 Issue. 2, February- 2021, pg. 24-36

ISSN: 2519-9889

Impact Factor: 3.426

The recovery studies were carried out at 30,40 and $50 \mu \mathrm{g} /$ mlconcentrations corresponding to 75,100 and $125 \%$ level. The mean $\%$ recovery \pm S.D. values corresponding to 3 levels were found to be $100.32 \pm 0.38,99.86 \pm 0.22$ and $100.01 \pm 0.44$ for resveratrol and $100.83 \pm 0.27,99.13 \pm 0.16$ and $99.13 \pm 0.16$ for Curcumin. The results are shown in Table 4. The proposed method was successfully applied for quantitation of resveratrol and curcumin in their combined Nanolipidgel formulation. The results for the assay were comparable with the corresponding amount added in Nanolipid gel formulation. Results for robustness evaluation for both the drugs are presented in Table 3. Insignificant differences in peak areas and less variability in retention times were observed. The $\%$ The LOD for resveratrol and curcumin were found to be 0.11 and $0.29 \mu \mathrm{g} / \mathrm{ml}$, respectively, while LOQ were 0.34 and $0.90 \mu \mathrm{g} / \mathrm{ml}$ respectively. Statistical analysis proved that the developed method was accurate, precise, and repeatable. Assay results for combined dosage form using proposed method showed $101.67 \pm 0.02$ of Resveratrol and $98.66 \pm 0.88 \%$ of Curcumin. Further this method can be extended to study the stress degradation behaviour of both the drugs in combination.

\section{Acknowledgement}

The authors are thankful to trustees of Sinhgad technical education society, for providing excellent analytical facilities. 


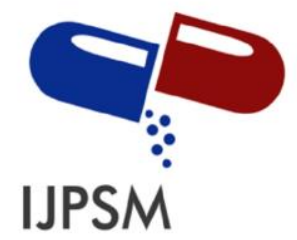

\section{Pooja Patil et al, Int. Journal of Pharmaceutical Sciences and Medicine (IJPSM), Vol.6 Issue. 2, February- 2021, pg. 24-36}

\section{References}

1. Singh G, Pai RP, Pandit V. 2012, Development and validation of a HPLC method for the determination of transresveratrol in spiked human plasma. J Adv. Pharm Tech Res, 3(2):130-35.

2. Resveratrol. Pennington Nutrition series Rev 2003, 11 available from https://www.pbrc.edu/training-andeducation/pdf/pns/PNS_Resveratrol.pdf

3. Priyadarshani KI. 2014, The chemistry of curcumin: from extraction to therapeutic agent. Molecules. 19: 20091-12

4. Gavhad G, Siesath V, Chaware V, Biyani K. 2005, Development and validation of RP-HPLC for the simultaneous determination of cinnamaldehyde and curcumin in pharmaceutical formulation of Lozenge. International J Pharm Chem Sci, 4(3):311-16

5. Curcumin. Chemical and Technical assessment. FAQ. 2004;1(8) available from https://www.researchgate.net/publication/285912691_Curcumin_chemical_and_Technical_Assessment_CTA

6. Gugulothu DB, Patravale VB, 2012, A new stability-indicating HPLC method for simultaneous determination of curcumin and celecoxib at single wavelength: an application to nanoparticle formulation. Pharmaceutica Anal Acta, 3(4):1-5

7. Chauhan AS, Pentek T, O’Brien B., 2017, Development of a topical Resveratrol formulation for commercial applications using Dendrimer Nanotechnology. Molecules, 22(137):1-16.

8. Caddeo C, Manconi M, Fadda AM, Lai F, Lampis S., 2013, Nanocarriers for antioxidant resveratrol: Formulation approach, vesicle self-assembly and stability evaluation. Colloids and surfaces B: Biointerfaces, 111:327-32

9. Basavaraj S, Betageri GV., 2014, Improved oral delivery of resveratrol using proliposomal formulation: investigation of various factors contributing to prolonged absorption of unmetabolized resveratrol. Expert opinion on drug delivery, 11 (4):493-03

10. Pando D, Matos M, Gutierrez G, Pazos C, 2015, Formulation of resveratrol entrapped niosomes for topical use. Colloids and surfaces B: Biointerfaces,128:398-04

11. Ahirrao M, Shrotriya SN, 2017, In vitro and in vivo evaluation of cubosomalin situ nasal gel containing resveratrol. Drug Development and Industrial Pharm, 7;1-8[doi:10.1080/03639045.2017.1338721]

12. Shrotriya SN, Ranpise NS, Vidhate BV, 2017, Skin targeting of resveratrol utilizing solid lipid nanoparticle-engrossed gel for chemically induced irritant contact dermatitis. Drug delivery and Translational Res. 7(1):37-52

13. Onoue S, Takahashi H, Kawabata Y, Seto Y, Hatanaka J, Timmermann B, 2010, Formulation design and photochemical studies on nanocrystal solid dispersion of curcumin with improved oral bioavailability. Journal of Pharm Sci, 2010;99(4):1871-81

14. Mukerjee A, Vishwantha JK., 2009, Formulation characterization and evaluation of curcumin-loaded PLGA nanospheres for cancer therapy. International J Cancer Res and Treatment, 29(10):3867-75

15. Zhang F,Koh GY, Jeansonne DP. Hollingsworth J. Russo PS. Vicente G. Stout RW. Liu Z., 2011, A novel solubilityenhanced curcumin formulation showing stability and maintenance of anticancer activity. J Pharm Sci, 100(7):277889

16. Coradini K, Limo F, Oliveira C, Chaves P, Athayde M, Carvalho L., 2014, Co-encapsulation of resveratrol and curcumin in lipid-core nanocapsules improves their in vitro antioxidant effects. European J Pharm Biopharm, 88(1):178-85

17. Vidhate B, Shrotriya SN, Vidhate M, Satpute P., 2015, Development and Validation of Simultaneous UVSpectrophotometric Method for the Determination of Silybin and Resveratrol in Pharmaceutical (In-House) Gel Formulation. American J Pharmtech Res, 5(4):157-65

18. Nikolic VD, Savic IM, Nikolic LB., 2015, Development and validation of an RP-HPLC method for quantification of trans-resveratrol in the plant extracts. Hem. Ind, 69(6):679-87[doi:10.2298/HEMIND140917004C]

19. Singh G, Pai R, Pandit V., 2012, Development and validation of a HPLC method for the determination of transresveratrol in spiked human plasma. $J$ adv. Pharm Tech Research, 3(2):30-35

20. Buiarelli F, Coccioli F, Jasionowska R, Merolle M, Terracciano A., 2006, Chromatographic analysis of TransResveratrol in Italian wines: Comparisons between FL, UV and MS detection. Chromatographia, 64(7-8):475-81

21. Sharma K, Agarwal SS, Gupta M., 2012, Development and validation of UV spectrophotometric method for the estimation of curcumin in bulk drug and pharmaceutical dosage form. International J drug develop Res, 4(2):375-80

22. Kadam PV, Bhingare CL, Nikam RV, Pawar SA., 2013, Development and validation of UV spectrophotometric method for the estimation of curcumin in cream formulation. Pharmaceutical methods, 4(2):43-45

23. Liu A, Lou H, Zhao L, Fan P., 2006, Validated LC/MS/MS assay for curcumin and tetrahydrocurcumin in rat plasma and application to pharmacokinetic study of phospholipid complex of Curcumin. J Pharm Biomedical Anal, 40(3):720-27 


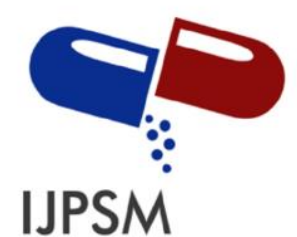

\section{Pooja Patil et al, Int. Journal of Pharmaceutical Sciences and Medicine (IJPSM), Vol.6 Issue. 2, February- 2021, pg. 24-36}

24. Ansari MJ, Ahmad S, Kohli K, Ali J, Khar RK. 2005, Stability-indicating HPTLC determination of curcumin in bulk drug and pharmaceutical formulations. Journal Pharm Biomedical Anal, 39(1-2):132-38

25. Dandekar PP, Patravale VB., 2009, Development and validation of a stability-indicating LC method for Curcumin. Chromatographia, 69(9-10):871-77

26. Li J, Jiang Y, Wen J, Fan G, Wu Y, Zhang C., 2009, A rapid and simple HPLC method for the determination of curcumin in rat plasma: assay development, validation and application to a pharmacokinetic study of curcumin liposome. Biomedical chromatography, 23(11):1201-07

27. Gonzales AM, Orlando RA, 2008, Curcumin and resveratrol inhibit nuclear factor-kappaB-mediated cytokine expression in adipocytes. Nutrition and Metabolics, 12(5)1-13

28. Mobasheri A, Henrotin Y, Biesalski H, Shakibaei M., 2012, Scientific evidence and rationale for the development of curcumin and resveratrol as neutraceuticals for joint health. International J Molecular Sciences, 13:4202-32

29. Majumdar AP, Banerjee S, Nautiyal J, Patel BB, Patel V, Du J., 2009, Curcumin synergizes with resveratrol to inhibit colon cancer. Nutrition and cancer, 61(4):544-53

30. ICH Guideline Q2(R1), Text on Validation of analytical Procedures Methodology, International Conference on Harmonization, J Geneva, November 2005.

\section{Author Biography}

Pooja Patil - Ms. Pooja Patil was a research scholar at Dept of Pharmaceutical Quality Assurance, Sinhgad College of Pharmacy. Her Research intereasts are development and validation of analytical method for Pharmaceuticals.

Shilpa Shrotriya - Dr. Mrs. Shilpa Shrotriya is Faculty of Pharmaceutics at dept of Pharmaceutics at Sinhgad College of Pharmacy, Pune. Her research areas mainly include formulation of lipidic and polymeric nanoparticles, new drug delivery systems, cosmoceuticals and neutraceuticals etc. She has 18 years of teaching experience and having twenty one research publications to her credit.

Sugandha Mulgund - Dr. Mrs. Sugandha V Mulgund is a Faculty of Pharmaceutical Chemistry at Sinhgad College of Pharmacy, Pune since last 17 years. Her research area mainly includes development and validation of analytical methods for quantitation of pharmaceuticals using HPLC and HPTLC, degradation studies on APIs, impurity profiling of APIs, standardisation of herbal components using analytical techniques etc. She has 28 research publications to her credit. 